\title{
Innovation network characteristics and equipment manufacturing industry upgrading: based on the mediating effect of innovation ability
}

\author{
Yue Li ${ }^{*}$, Bobo Guo, Xiaoyan Sun and Xiaoli Li \\ School of Economics and Management, Harbin University of Science and Technology, Harbin \\ 150080, China
}

\begin{abstract}
In order to strengthen the guiding and supporting role of the innovation-driven development strategy, and to promote the structural optimization and efficiency improvement of the equipment manufacturing industry, this paper analyzes the structure, function and characteristics of the regional equipment manufacturing industry innovation network, and proposes a conceptual model and theoretical hypothesis that the innovation network based on the mediating effect of innovation capability affects the upgrade effect of the regional equipment manufacturing industry. Through a questionnaire survey of 219 enterprises in my country's equipment manufacturing industry and structural equation model verification, it measures the action path and industrial upgrading law of innovation network influencing regional equipment manufacturing industry upgrading.
\end{abstract}

\section{Introduction}

Our country is a large manufacturing country rather than a powerful country. Although the equipment self-sufficiency rate reaches $85 \%$, it is mainly concentrated in the low-end market, and high-end equipment still relies on imports. In 2015, the State Council promulgated "Made in China 2025", which is the first ten-year action plan for the Chinese government to implement the strategy of a manufacturing powerhouse, which provides opportunities and conditions for promoting the transformation and upgrading of my country's equipment manufacturing industry.

Industrial upgrading refers to the improvement of industrial structure and the improvement of industrial quality and efficiency. Gereffi (2001) put forward the concept of global value chain (GVC) when analyzing the problems of industrial connections and industrial upgrading on a global scale ${ }^{[1]}$. Industrial upgrading was then introduced into the analysis framework of GVC, which is divided into process upgrade, product upgrade, and function Upgrading and chain upgrading (Humphrey, 2001). Humphrey (2004) believes that with the globalization of the industrial value chain, global trade-based assembly $\rightarrow \mathrm{OEM} \rightarrow \mathrm{ODM} \rightarrow \mathrm{OBM}$ has become an important choice for the industrial

\footnotetext{
*Corresponding author: lykusha@163.com
} 
upgrading path of developing countries ${ }^{[2]}$. Intensified global market competition has also promoted domestic industrial upgrading ${ }^{[3]}$, but industrial upgrading is also restricted by factors such as knowledge stock, technical capabilities, and regional characteristics. Giuliani (2005) pointed out that the key to industrial upgrading lies in the inter-enterprise organizational model and value chain governance issues, and the degree of knowledge accumulation and the specificity, coding and complexity of the knowledge base will affect the upgrading ability and path $^{[4]}$.Arash (2011) investigated the impact of industrial upgrading on innovation performance ${ }^{[5]}$, and the positive correlation between industrial upgrading and developmental innovation has partially adjusted the impact on exploratory innovation ${ }^{[6]}$.

Zhang Wanli (2020) uses the panel fixed effect model to analyze the static and dynamic effects of industrial intelligence on the advancement and rationalization of industrial structure, and concludes that industrial intelligence has a positive effect on the advancement of industrial structure, but has a negative effect on rationalization ${ }^{[7]}$. Yang Jin (2020) used the fuzzy set qualitative comparative analysis method to explore the key influencing factors and the path of action in the transformation and upgrading of the equipment manufacturing industry driven by subversive innovation, and extracted innovative technology (product) incubation, market selection, and innovation strategy selection and the four key influencing factors of market disruption, summed up two transformation and upgrading paths of market type and innovation strategy type ${ }^{[8]}$. Yin (2020) combined the characteristics of the marine equipment manufacturing industry, used the network connection strength to evaluate the intelligent clusters manufactured by equipment, and concluded that the intelligent clustering evaluation method based on the network connection strength is more effective than the traditional method ${ }^{[9]}$.Qi (2020) designed a virtual alliance-based analysis method for key factors in the transformation of the port equipment manufacturing industry's production service industry, and analyzed the technological transformation and product transformation of the port equipment manufacturing industry ${ }^{[10]}$. This design method has more advantages than the traditional method after transformation ${ }^{[11]}$. With good service effect, the overall service effect after transformation has been greatly improved ${ }^{[12]}$.

To sum up, domestic and foreign scholars mostly focus on the research of industrial upgrading from the perspective of global value chain, but have little involvement in the endogenous industrial upgrading driven by regional roots and industrial characteristics advantages; in addition, although a few scholars are focusing on the industrial upgrading path, but has not systematically given a specific industrial upgrade path design method, which is insufficient to guide industrial development and upgrading practice. Therefore, this paper systematically studies the impact of innovation drivers on the upgrading of regional equipment manufacturing industries from the perspective of networks, in order to give full play to the role of innovation-driven guidance and support and improve the upgrading efficiency of the regional equipment manufacturing industry.

\section{Theoretical model and hypothesis}

\subsection{Theoretical model}

This paper constructs a theoretical model of the role of innovation networks in upgrading regional equipment manufacturing, as shown in Figure 1.

The model as a whole is represented as a structural model, in which there are six potential variables: network centrality, network scale, network relationship strength, network relationship stability, innovation capability, and industrial upgrading effect, of which industrial innovation capability is the intermediary variable. 


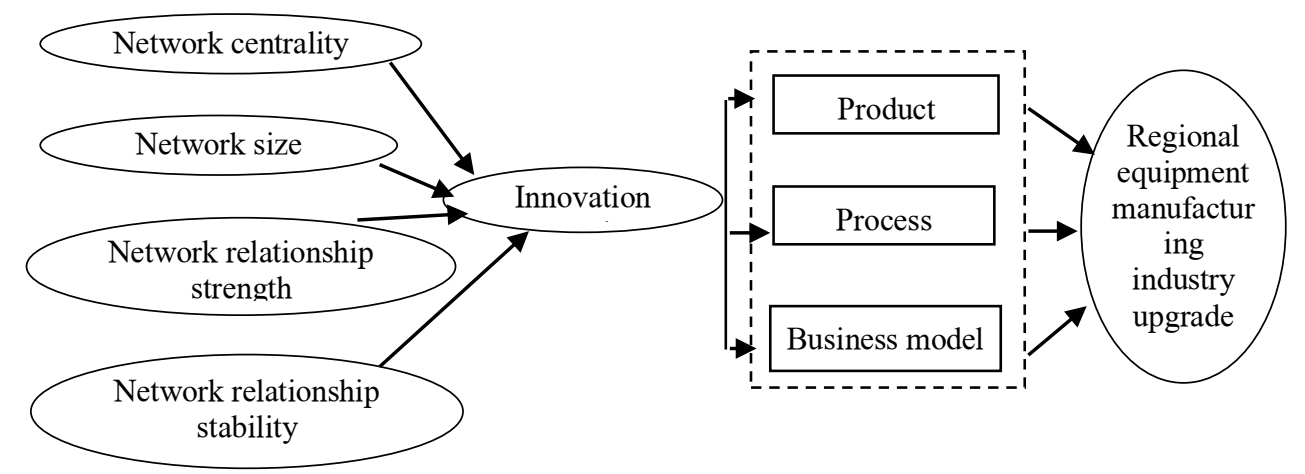

Fig. 1. Theoretical model.

\subsection{Hypothesis}

(1)The relationship between innovation ability and equipment manufacturing upgrade.

The influence of innovation ability on the upgrading of regional equipment manufacturing industry is mainly manifested as follows: First, product innovation enhances the added value of equipment manufacturing products through improvement or creation of new products.Second, Process innovation improves production efficiency through the application of new equipment, processes and management methods in the production process, thereby promoting the upgrading of regional equipment manufacturing.Third, the business model innovation ability promotes the upgrading of regional equipment manufacturing, Based on the above analysis, this article proposes the following hypotheses:

H5a: Product innovation is positively correlated with regional equipment manufacturing industry upgrading;

H5b: Process innovation is positively correlated with regional equipment manufacturing industry upgrading;

H5c: Business model innovation is positively correlated with regional equipment manufacturing industry upgrading.

(2)The influence of network centrality on innovation capabilities.

Network centrality is mainly used to measure the degree of participation of actors in network relationships, to evaluate the importance of each node, the superiority of the node and social prestige, and the possibility of the node to obtain and control resources and information. Based on the above analysis, this article proposes the following hypotheses:

H1a: Network centrality is positively correlated with product innovation capability;

H1b: Network centrality is positively correlated with process innovation capability;

H1c: Network centrality is positively correlated with business model innovation ability.

(3)The influence of network size on innovation capabilities.

With the expansion of the network scale, the sources of innovation resources have been expanded, and more innovation entities (network nodes), innovation resources (network resources) and other innovative elements have been embedded in the innovation network, which will help the development of network innovation activities and promote the innovation ability of the company's products, processes, and business models. Based on the above analysis, this article proposes the following hypotheses:

H2a: Network scale is positively correlated with product innovation capability;

$\mathrm{H} 2 \mathrm{~b}$ : Network scale is positively correlated with process innovation capability;

$\mathrm{H} 2 \mathrm{c}$ : Network scale is positively correlated with business model innovation capability.

(4)The influence of network relationship strength on innovation ability. 
The stronger the network relationship, the more conducive to the interaction of node resources and the development of collaborative innovation activities, accelerating the generation and integration of innovations such as knowledge and technology, and promoting the main body carries out product, process and business model innovation activities to continuously improve innovation capabilities. Based on the above analysis, this article proposes the following hypotheses:

H3a: Network relationship strength is positively correlated with product innovation;

$\mathrm{H} 3 \mathrm{~b}$ : Network relationship strength is positively correlated with process innovation;

H3c: Network relationship strength is positively correlated with business model innovation.

(5)The influence of network relationship stability on innovation ability.

Through mutual trust and mutual benefit between the two parties, related technologies, knowledge and other resources can be smoothly transferred, absorbed, and created, so that the innovation entities can carry out innovation activities and continuously improve innovation ability.Based on the above analysis, this article proposes the following hypotheses:

H4a: Network relationship stability is positively correlated with product innovation;

H4b: Network relationship stability is positively correlated with process innovation;

H4c: Network relationship stability is positively correlated with business model innovation.

\section{Empirical research}

\subsection{Variable design and measurement index selection}

This article intends to start with innovation network characteristic variables, innovation capability variables and equipment manufacturing upgrade variables. In the specific measurement of variables, the Likert five-level scale is mainly used to divide it into five levels: 1-very dissatisfied, 2-unsatisfied, 3-fair, 4-satisfied, 5-very satisfied.

Innovation network variables are mainly selected from four indicators of network centrality, network scale, network relationship strength and network relationship stability. The paper uses three indicators of product innovation capability, process innovation capability, and business model innovation capability to measure the innovation capability of the regional equipment manufacturing industry. And uses three items including the improvement of equipment manufacturing production efficiency, the improvement of product added value and the optimization of value chain to measure the upgrading of the regional equipment manufacturing industry. The item design is shown in Table 1.

Table 1. Measurement variables and items.

\begin{tabular}{|c|c|c|}
\hline Variable name & Item & source \\
\hline \multirow{3}{*}{ Network centrality (A) } & $\begin{array}{l}\text { Most companies are willing to establish a } \\
\text { relationship with your company :A1 }\end{array}$ & \multirow{3}{*}{$\begin{array}{l}\text { Powell } \\
(1996) ; \text { Tsai } \\
(2001) \text {;Yu Dengke } \\
(2006) \text {;Zhao } \\
\text { Hongmei } \quad(2011)\end{array}$} \\
\hline & $\begin{array}{l}\text { Through a small number of intermediary } \\
\text { nodes, it can establish relationships with most } \\
\text { nodes in the network :A2 }\end{array}$ & \\
\hline & $\begin{array}{l}\text { Able to cooperate with highly prestigious } \\
\text { companies or institutions : } 33\end{array}$ & \\
\hline \multirow[t]{2}{*}{ Network size(B) } & $\begin{array}{l}\text { Compared with peers, there are many } \\
\text { companies or institutions that directly establish } \\
\text { cooperative relations : } 1 \text { 1 }\end{array}$ & \multirow{2}{*}{$\begin{array}{l}\text { Liu Jun } \\
(2006) \text {;Wang } \\
\text { Xiaojuan } \\
(2008) \text {;Senjem }\end{array}$} \\
\hline & $\begin{array}{l}\text { Compared with peers, there are a lot of } \\
\text { companies or institutions indirectly met }\end{array}$ & \\
\hline
\end{tabular}




\begin{tabular}{|c|c|c|}
\hline & through cooperation :B2 & (2002) ;Zhao \\
\hline & $\begin{array}{l}\text { Compared with peers, the total number of } \\
\text { enterprises or institutions that have established } \\
\text { relationships directly and indirectly:B3 }\end{array}$ & Hongmei (2011) \\
\hline & $\begin{array}{l}\text { More frequent cooperation with other } \\
\text { companies or institutions : } \mathrm{C} 1\end{array}$ & $\begin{array}{l}\text { Eisingerich } \\
(2010) ; \text { Luo }\end{array}$ \\
\hline & $\begin{array}{l}\text { Frequent visits and visits to other } \\
\text { companies or institutions : } \mathrm{C} 2\end{array}$ & $\begin{array}{l}\text { Zhiheng } \\
(2009) ; \text { Granovetter }\end{array}$ \\
\hline $\begin{array}{l}\text { Network relationship } \\
\text { strength (C) }\end{array}$ & $\begin{array}{l}\text { Informal social activities such as meetings } \\
\text { with other companies or institutions are more } \\
\text { frequent }: \mathrm{C} 3\end{array}$ & $\begin{array}{l}(1995) \text {; Dyer } \\
(2003) \text {; Chen }\end{array}$ \\
\hline & $\begin{array}{l}\text { In the process of cooperation, mutual trust } \\
\text { is high :C4 }\end{array}$ & \\
\hline & Stable relationship with customers :D1 & Granvetter \\
\hline & Stable relationship with suppliers :D2 & Rokkan \\
\hline relationship & $\begin{array}{l}\text { Stable relationship with universities and } \\
\text { research institutes :D3 }\end{array}$ & Hongmei $(2011)$ \\
\hline & $\begin{array}{l}\text { The relationship with the intermediary is } \\
\text { more stable :D4 }\end{array}$ & \\
\hline & $\begin{array}{l}\text { More stable relations with financial } \\
\text { institutions :D5 }\end{array}$ & \\
\hline & Speed up new product development :E1 & Hong Ruyan \\
\hline $\begin{array}{l}\text { Product innovation } \\
\text { capability (E) }\end{array}$ & $\begin{array}{l}\text { Higher success rate of new product } \\
\text { development :E2 }\end{array}$ & \\
\hline & $\begin{array}{l}\text { The output value of new products accounts } \\
\text { for a higher proportion of total sales : } \mathrm{E} 3\end{array}$ & \\
\hline & $\begin{array}{l}\text { Stronger corporate technological } \\
\text { transformation capabilities :F1 }\end{array}$ & $\begin{array}{l}\text { Hong Ruyan } \\
\text { (2012) }\end{array}$ \\
\hline innovation capability & $\begin{array}{l}\text { Enterprise technology is more } \\
\text { advanced :F2 }\end{array}$ & \\
\hline & $\begin{array}{l}\text { Production management methods are very } \\
\text { advanced :F3 }\end{array}$ & \\
\hline & $\begin{array}{l}\text { The company's business model is } \\
\text { innovative :G1 }\end{array}$ & $\begin{array}{l}\text { Guo Yifu } \\
\text { (2009) ;Wang Tong }\end{array}$ \\
\hline innovation capability & $\begin{array}{l}\text { The company's profit model has been } \\
\text { innovative :G2 }\end{array}$ & $\begin{array}{l}\text { (2015) ;Xiao Ting } \\
\text { (2013) ;Li Hong }\end{array}$ \\
\hline & $\begin{array}{l}\text { Customers are satisfied with the products } \\
\text { or services provided by your company :G3 }\end{array}$ & (2012) \\
\hline regional equipment & Product added value enhancement $: \mathrm{H} 1$ & Chen Aizhen \\
\hline manufacturing & Value chain optimization :H2 & $(2008)$;Wang \\
\hline$(\mathrm{H})$ & Increased production efficiency :H3 & \\
\hline
\end{tabular}

\subsection{Data acquisition and effectiveness control}

(1) Data sources.The equipment manufacturing industry was selected as the survey object. This study lasted 3 months from March 2016 to June 2016. 250 copies of the questionnaire survey trading platform were issued and 150 valid questionnaires were returned (the designated industry is the equipment manufacturing industry), and 110 copies of valid questionnaires were distributed to Harbin University of Science and Technology, Harbin Engineering University and other colleges such as MBA, MEM, and engineering masters students and 69 valid questionnaires were recovered. The final valid questionnaire was 219 , with an effective recovery rate of $60.8 \%$. 
(2) Reliability test.Using SPSS19.0 software to carry out reliability test, with Cronbach's coefficient greater than 0.7 as the eligibility standard, the running results are between 0.8 and 0.93 , indicating that the reliability of each variable is good.

(3) Validity analysis. This research questionnaire is based on the design of items and scales based on relevant domestic and foreign research, and has been discussed and revised many times, so the questionnaire has high content reliability. Using Liserl software for exploratory factor analysis, the results show that the variable combination reliability (VE) exceeds the standard of 0.7 , and the AVE also exceeds the standard of 0.5 , indicating that the variables have good convergence validity and confirmatory factors for the three latent variables. The above all indicate that the questionnaire of this study has good construct validity.

\subsection{Hypothesis testing and model testing}

(1) Model checking and correction.Judging from the verification results of the original model, the overall fit of the model is not high. Correct the original model according to the MI correction index and the reduction path to obtain the final model, as Figure 2.

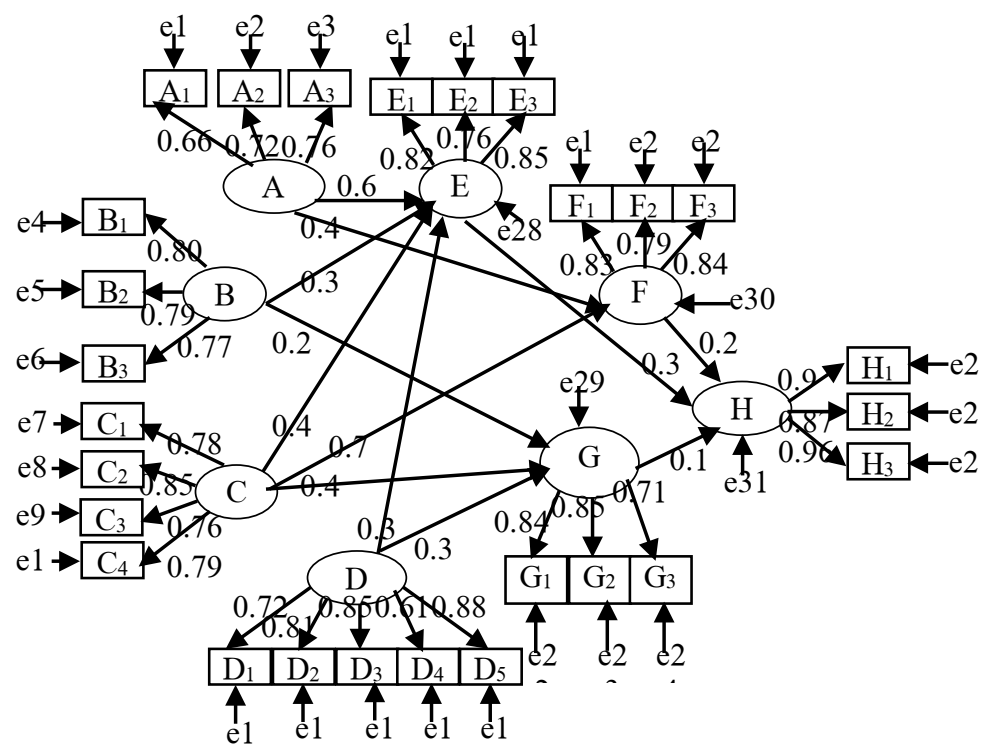

Fig. 2. Standardized path SEM model.

(2) Hypothesis test analysis.Use Liserl software to obtain the corresponding and t value of the standardized path coefficient estimates between the latent variables and compare it with the test standard ( $\mathrm{t}>1.96)$. It is found that: $\mathrm{H} 1 \mathrm{c}, \mathrm{H} 2 \mathrm{~b}$ and $\mathrm{H} 4 \mathrm{c}$ hypothetical paths are not significant and cannot pass the test, as shown in Table 2.

\section{Conclusions and prospects}

Based on the results of a questionnaire survey of 219 enterprises in my country's equipment manufacturing industry, this paper uses a structural equation model to measure the role of innovation networks influencing regional equipment manufacturing upgrades and the laws of industrial upgrading. The research results show that: innovation ability will affect the upgrading of equipment manufacturing industry, and it is positively correlated. 
Table 2. Path coefficient estimation

\begin{tabular}{|c|c|c|c|}
\hline Path & Standardized path & t value & Whether the hypothesis holds \\
\hline H1a & 0.63 & 2.03 & $\mathrm{Y}$ \\
\hline $\mathrm{H} 1 \mathrm{~b}$ & 0.44 & 2.28 & $\mathrm{Y}$ \\
\hline $\mathrm{H} 1 \mathrm{c}$ & 0.11 & 0.88 & $\mathrm{~N}$ \\
\hline $\mathrm{H} 2 \mathrm{a}$ & 0.34 & 4.19 & $\mathrm{Y}$ \\
\hline $\mathrm{H} 2 \mathrm{~b}$ & 0.12 & 1.55 & $\mathrm{Y}$ \\
\hline $\mathrm{H} 2 \mathrm{c}$ & 0.26 & 2.96 & $\mathrm{Y}$ \\
\hline $\mathrm{H} 3 \mathrm{a}$ & 0.41 & 3.22 & $\mathrm{Y}$ \\
\hline $\mathrm{H} 3 \mathrm{~b}$ & 0.75 & 4.02 & $\mathrm{Y}$ \\
\hline $\mathrm{H} 3 \mathrm{c}$ & 0.40 & 3.35 & $\mathrm{Y}$ \\
\hline $\mathrm{H} 4 \mathrm{a}$ & 0.38 & 4.27 & $\mathrm{Y}$ \\
\hline $\mathrm{H} 4 \mathrm{~b}$ & 0.36 & 6.90 & $\mathrm{~N}$ \\
\hline $\mathrm{H} 4 \mathrm{c}$ & 0.74 & 1.19 & $\mathrm{Y}$ \\
\hline $\mathrm{H} 5 \mathrm{a}$ & 0.31 & 9.78 & $\mathrm{Y}$ \\
\hline $\mathrm{H} 5 \mathrm{~b}$ & 0.27 & 4.19 & $\mathrm{Y}$ \\
\hline $\mathrm{H} 5 \mathrm{c}$ & 0.18 & 8.53 & \\
\hline
\end{tabular}

However, there is a lack of analysis on the evolution law of innovation network and the process and law of regional equipment manufacturing upgrade. Follow-up research can consider this aspect, reveal the coupling relationship between the two, and lay the foundation for designing the upgrade path of regional equipment manufacturing industry.

This work was partially supported by the National Natural Science Foundation of China (No. 71704036), the Philosophy and Social Science Planning Project of Heilongjiang Province (No. 20GLB119; 20JYB033), and the Outstanding Young Talent Project of Talents Plan of Harbin University of Science and Technology (No.2019-KYYWF-0216).

\section{References}

1. G Gereffi. Am Behav Sci, 10,44(2001)

2. J Humphrey. Working Paper: International Labour Organization,(2004)

3. L Brandt, E Thun.World Dev, 5,38, 1555-1574 (2010)

4. E Giuliani, Carlo Pietrobelli. World Dev,4,33,549-573(2005)

5. A Arash, W M Stephan.Int J Prod Econ, 3, 54-65 (2011)

6. X Zhong,G.X. Zang,F.F. Wu. Sustainability-Basel, 5,11(2019).

7. W.L. Zhang, Y Xuan, B Sui, W Wei. Studies in Science of Science,12,1-13 (2020)

8. J Yang, R.L. Xie. Forum on Science and Technology in China, 11,74-82+109(2020)

9. L Yin. J Coastal Res, sp1,103,900-904 (2020)

10. C. N. Ngo. J Econ Issues, 4,50(2016)

11. L.Q. Qi, C Wang, C.D. Wang. J Coastal Res, sp1,103,654-657(2020).

12. C. Wang,X.Y. Zhang, L.M. Vilela,C. Liu, Physica A,(2018) 